\title{
Comparison of the Amplisure HBV Quantitative Kit with the Qiagen Artus HBV QS-RGQ Assay for Quantifying Viral DNA in Plasma Samples of Monitoring Cases
}

\author{
Ganesan Praveenkumar $^{\mathrm{a}}$ Chaitali Nikam $^{\mathrm{b}}$ Ragoori Venkata Ramana ${ }^{\mathrm{c}}$ \\ Sengupta Caesar ${ }^{d}$ Velumani Amruta $^{d}$ Ahmad Riyaj $^{d}$ \\ aMolecular Biology, Thyrocare Technologies Limited, Navi Mumbai, India; ${ }^{\mathrm{b}}$ Infectious Diseases, Thyrocare \\ Technologies Limited, Navi Mumbai, India; 'RAS Life Sciences Pvt. Limited, Hyderabad, India; ${ }^{\text {T}}$ Thyrocare \\ Technologies Limited, Navi Mumbai, India
}

\section{Keywords}

Hepatitis B virus · Chronic hepatitis B · Viral load · Treatment monitoring

\begin{abstract}
Background: Monitoring of hepatitis B virus (HBV) viral load has become an essential phase in the treatment of HBV. There are many commercial assays available for HBV viral load quantification. In this study, we have evaluated the performance characteristics of Amplisure ${ }^{\oplus} \mathrm{HBV}$ Kit in comparison with the Qiagen artus HBV QS-RGQ kit for HBV DNA quantitation. Methods: Comparison of 2 methods was carried out on 200 clinical samples, $150 \mathrm{HBV}$ DNA positive and 50 HBV DNA negative, by a reference method. Results obtained with Amplisure ${ }^{\circledR}$ HBV Kit (Amplisure HBV) were compared using the Qiagen artus HBV QS-RGQ assay results as the comparator method. Result: The overall performance of the Amplisure HBV compared with the comparator method shows positive and negative clinical agreement of 100 and $76 \%$, respectively. Among the 12 qualitative discrepant samples, all positive with Amplisure HBV were sequenced and 10 were below comparator method's LOD. For 5 weak positives $(-0.22$ to $0.98 \log \mathrm{IU} / \mathrm{mL})$, the sequencing failed. The 7 other positives ( 0.48 to $1.89 \mathrm{log} \mathrm{IU} / \mathrm{mL}$ ) were confirmed positive by
\end{abstract}

sequencing. Quantitative comparison gave an $r^{2}$ of 0.967 with a mean log difference of $0.09 \log _{10} \mathrm{IU} / \mathrm{mL}$. Conclusion: This study shows that Amplisure ${ }^{\circledR} \mathrm{HBV}$ Quantitative Kit shows comparable performance with artus HBV QS-RGQ assays and can be useful in management and therapeutic monitoring of $\mathrm{HBV}$ in a clinical practice.

(c) 2021 The Author(s)

Published by S. Karger AG, Basel

\section{Introduction}

Hepatitis B virus (HBV) infection is still a major health concern all over the world. Globally, an estimated 257 million people are infected with $\mathrm{HBV}$, defined as $\mathrm{HBsAg}$ positive. In 2015 , an estimated $8,87,000$ deaths have occurred because of chronic HBV mainly due to complications such as cirrhosis and hepatocellular carcinoma [1]. Hepatitis B (Hep B) prevalence is the highest in the Western Pacific region and the African region, 6.2 and 6.1\%, respectively. Also, in adult population, it is estimated 3.3, 2.0, and $1.6 \%$ in eastern Mediterranean region, Southeast Asia region, and European region, respectively.

In India, prevalence of $\mathrm{HBsAg}$ is $3-4.2 \%$ with over 40 million HBV carriers, and every year over 1,15,000 Indians die of HBV-related complications. There are 10
C 2021 The Author(s).

Published by S. Karger AG, Basel

This is an Open Access article licensed under the Creative Commons Attribution-NonCommercial-4.0 International License (CC BY-NC) (http://www.karger.com/Services/OpenAccessLicense), applicable to the online version of the article only. Usage and distribution for commercial purposes requires written permission.
Correspondence to:

Chaitali Nikam, chaitali_nikam@ymail.com 
known HBV genotypes, classified from A to J, all found in India. The most common genotype in India is D, followed by $\mathrm{A}$ and $\mathrm{C}$ [2-4]. Molecular testing using real-time PCR (RT-PCR) has made a big impact on viral HBV quantification. HBV DNA measurements play a critical role in determining the phase of infection, deciding the treatment, and detecting responses to the antiviral therapy $[5,6]$. According to the guidelines for the prevention, care, and treatment for persons with chronic hepatitis $\mathrm{B}$ (CHB) infection from the World Health Organization and China, HBV DNA quantification is recommended in the treatment of CHB infections. [6].

The application of RT-PCR for viral diagnostics has been stated to reveal high sensitivity, a broad dynamic range, and short turnaround time, considered as the standard method for quantification [7, 8]. It is important to implement a highly reliable PCR-based assay to quantify HBV DNA in order to enable appropriate clinical management of Hep B infection. To date, many HBV DNA assays are commercially available [9-11]. In our study, we have verified the performance of the Amplisure ${ }^{\circledR} \mathrm{HBV}$ Quantitative Kit in comparison with the Qiagen artus HBV QS-RGQ assay for HBV DNA quantification.

\section{Materials and Methods}

Flow of the study of Amplisure ${ }^{\circledR}$ HBV Quantitative Kit as compared to the comparator method is shown in Figure 1.

Settings

Sample collection was done by a Thyrocare service provider; DNA extraction and PCR assay was performed at Thyrocare Technologies Ltd., Turbhe, Navi Mumbai; and discrepant results were sequenced by RAS Lifesciences Pvt., Ltd., Hyderabad, through outsourcing to a contract research service provider.

Study Population and Specimens

This was a single-site, blinded, validation study to evaluate the performance of the Amplisure HBV Quantitative Kit considering Qiagen artus HBV QS-RGQ assay results as the comparator method. A total of 200 EDTA plasma samples were included in the study, which were received for routine testing for HBV viral load monitoring by the Thyrocare Laboratory. After processing and reporting the results by the laboratory, the leftover plasma samples that were adequate in quantity were selected for processing further with blinded numbers. The samples used for this study were selected from April 2018 to May 2018.

Artus HBV QS-RGQ Assay (Method 1 - Comparator)

Nucleic acid (60 $\mu \mathrm{L}$ HBV DNA) was extracted from $200 \mu \mathrm{L}$ plasma by using the QIAsymphony SP and PCR assay and the DSP Virus Mini Pathogen Kit. Setup was performed on QIAgility using artus HBV QS-RGQ assay manufactured by Qiagen, Germany. QIAgility is a liquid dispenser; it mixes the DNA and master mix.

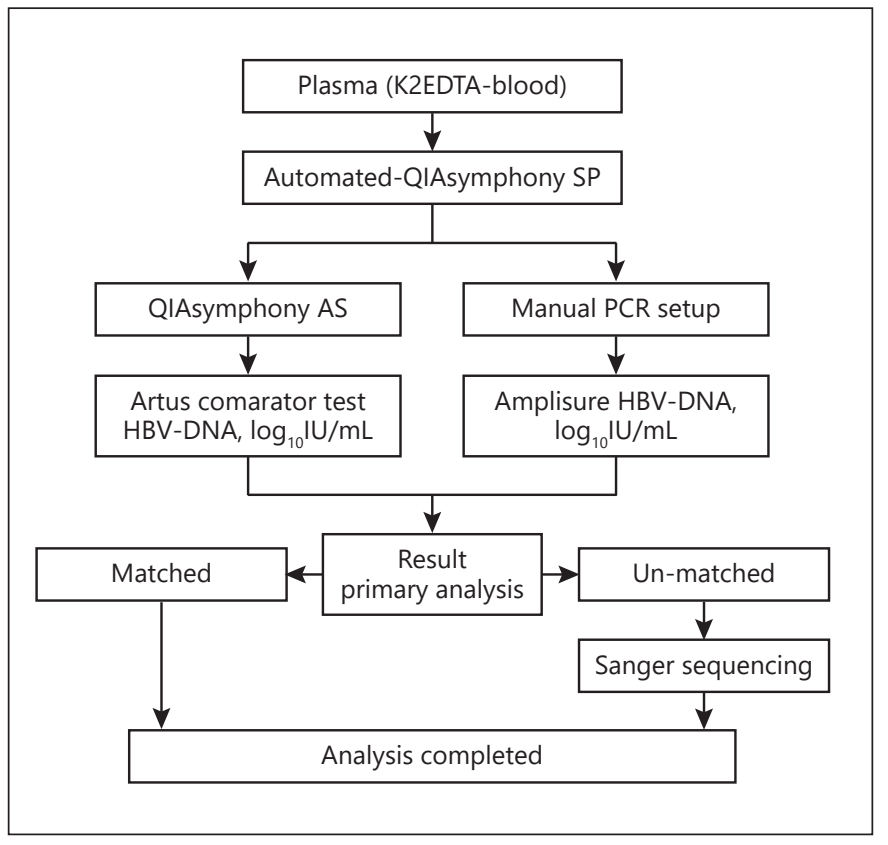

Fig. 1. Study design for evaluation of Amplisure HBV Quantitative Kit.

The assay contains reagents and enzymes for the specific amplification of a 134-bp region of the HBV genome. Five quantitative standards and NTC were incorporated in each batch for accurate quantification of HBV DNA viral load in samples as per manufacturer's recommendations. Rotor Gene Q was used for RT-PCR. The thermal cycling condition was followed as per manufacturer's instruction. The results were analyzed using RGQ software version 2.3.1 by setting the threshold between 0.03 and 0.05 . The laboratory verified the limit of detection (LOD) of the assay by using the 4th WHO international standard for HBV DNA for NAT (NIBSC code: 10/266) procured from NIBSC, and the standard was serially diluted (stock 955000, 19100, 1910, 191, 95.5, and 47.75) and tested in duplicates as per protocol. Laboratory-derived LOD of the assay is $40 \mathrm{IU} / \mathrm{mL}$, and the linear range of the assay is from $4 \times$ $10^{1}$ to $2 \times 10^{7} \mathrm{IU} / \mathrm{mL}$.

\section{Amplisure ${ }^{\circledR}$ HBV Quantitative Kit (Method 2 - Amplisure} HBV)

DNA (60 $\mu$ L HBV DNA) extracted for the reference test by using the QIAsymphony SP instrument with DSP Virus Mini Pathogen Kit manufactured by Qiagen, Germany, was used. The assay contains reagents and enzymes for the amplification of a specific region (S gene) of the pathogen genome. The PCR assay setup was done manually with a reaction volume of $5 \mu \mathrm{L}$ DNA and $20 \mu \mathrm{L}$ master mix by using Amplisure ${ }^{\circledR}$ HBV Quantitative Kit [12] manufactured by RAS Lifesciences, India. RT-PCR was performed on the Rotor Gene Q instrument as per the assay procedure recommended by the manufacturer. Four quantification standards and NTC were run in each batch for accurate quantification of HBV DNA viral load in samples. The results were analyzed using RGQ Software V2.3.1 by setting the threshold at 0.06 . LOD of the assay was verified by using the 4 th WHO international standard for 
Table 1. Primer sequences used for HBV genotyping by nested PCR

\begin{tabular}{ll}
\hline Primer & Sequence \\
\hline $\begin{array}{l}\text { First PCR } \\
\text { P1 }\end{array}$ & 5'-TCA CCA TAT TCT TGG GAA CAA GA-3' (nt 2,823-2,845, universal, sense) \\
S1-2 & $5^{\prime}$-CGA ACC ACT GAA CAA ATG GC-3' (nt 685-704, universal, antisense) \\
\hline Second PCR & \\
Mix A & \\
B2 & $5^{\prime}$-GGC TCM AGT TCM GGA ACA GT-3' (nt 67-86, types A to E specific, sense) \\
BA1R & $5^{\prime}$-CTC GCG GAG ATT GAC GAG ATG T-3' (nt 113-134, type A specific, antisense) \\
BB1R & $5^{\prime}$-CAG GTT GGT GAG TGA CTG GAG A-3' (nt 324-345, type B specific, antisense) \\
BC1R & $5^{\prime}$-GGT CCT AGG AAT CCT GAT GTT G-3' (nt 165-186, type C specific, antisense) \\
Mix B & \\
BD1 & $5^{\prime}$-GCC AAC AAG GTA GGA GCT-3' (nt 2,979-2,996, type D specific, sense) \\
BE1 & $5^{\prime}$-CAC CAG AAA TCC AGA TTG GGA CCA-3' (nt 2,955-2,978, type E specific, sense) \\
BF1 & $5^{\prime}$-GYT ACG GTC CAG GGT TAC CA-3' (nt 3,032-3,051, type F specific, sense) \\
B2R & $5^{\prime}$-GGA GGC GGA TYT GCT GGC AA-3' (nt 3,078-3,097, types D to F specific, antisense) \\
\hline
\end{tabular}

HBV DNA for NAT (NIBSC code: 10/266) procured from NIBSC, and a single concentration of $18 \mathrm{IU} / \mathrm{mL}$ was prepared from the standard and was extracted 20 times with High Pure Viral Nucleic Acid Kit. Two hundred microliters of the sample $+10 \mu \mathrm{L}$ of IC2 were coextracted and eluted in $50 \mu \mathrm{L}$ of elution buffer. All the extracted samples were amplified in a single amplification run on Bio-Rad CFX 96 with the Amplisure ${ }^{\circledR}$ HBV Quantitative Kit, LOD of the assay is determined as $18 \mathrm{IU} / \mathrm{mL}(\mathrm{CI}: 11-37 \mathrm{IU} / \mathrm{mL})$, and the linear range of the assay is from 25 to $1.25 \times 10^{10} \mathrm{IU} / \mathrm{mL}$.

\section{Nested PCR and Sequencing}

Discrepant DNA samples were reamplified by nested PCR by using type-specific primers (Table 1). We amplified the HBV genome by nested PCR using the universal primers (P1 and S1-2) for the outer primers, followed by 2 different mixtures containing type-specific inner primers. The first PCR was carried out with the following thermal cycling conditions: first incubating the samples for $10 \mathrm{~min}$ at $95^{\circ} \mathrm{C}$, followed by 40 cycles consisting of $94^{\circ} \mathrm{C}$ for 20 $\mathrm{s}, 55^{\circ} \mathrm{C}$ for $20 \mathrm{~s}$, and $72^{\circ} \mathrm{C}$ for $1 \mathrm{~min} ; 2$ second-round PCRs were performed for each sample, with the common universal sense primer (B2) and mix A for types A through $\mathrm{C}$ and the common universal antisense primer (B2R) and mix B for types D through F. A $1-\mu \mathrm{L}$ aliquot of the first PCR product was added to 2 tubes containing the second sets of each of the inner primer pairs and each of the deoxynucleotides, AmpliTaq Gold DNA polymerase, and PCR buffer, as in the first reaction. These were amplified for 40 cycles with the following parameters: preheating at $95^{\circ} \mathrm{C}$ for 10 min, 20 cycles of amplification at $94^{\circ} \mathrm{C}$ for $20 \mathrm{~s}, 58^{\circ} \mathrm{C}$ for $20 \mathrm{~s}$, and $72^{\circ} \mathrm{C}$ for $30 \mathrm{~s}$, and an additional $20 \mathrm{cycles}$ of $94^{\circ} \mathrm{C}$ for $20 \mathrm{~s}, 60^{\circ} \mathrm{C}$ for $20 \mathrm{~s}$, and $72^{\circ} \mathrm{C}$ for $30 \mathrm{~s}$ [13]. The PCR products were purified using ExoSAP treatment according to the manufacturer's instructions [14]. The concentration and quality of PCR products was checked by agarose gel electrophoresis. The samples were sequenced by both forward and reverse primers. After ethanol precipitation, the purified PCR products were subjected to sequencing by using Applied Biosystems 3730xl DNA Analyzer (ABI), and results were generated after data analysis.

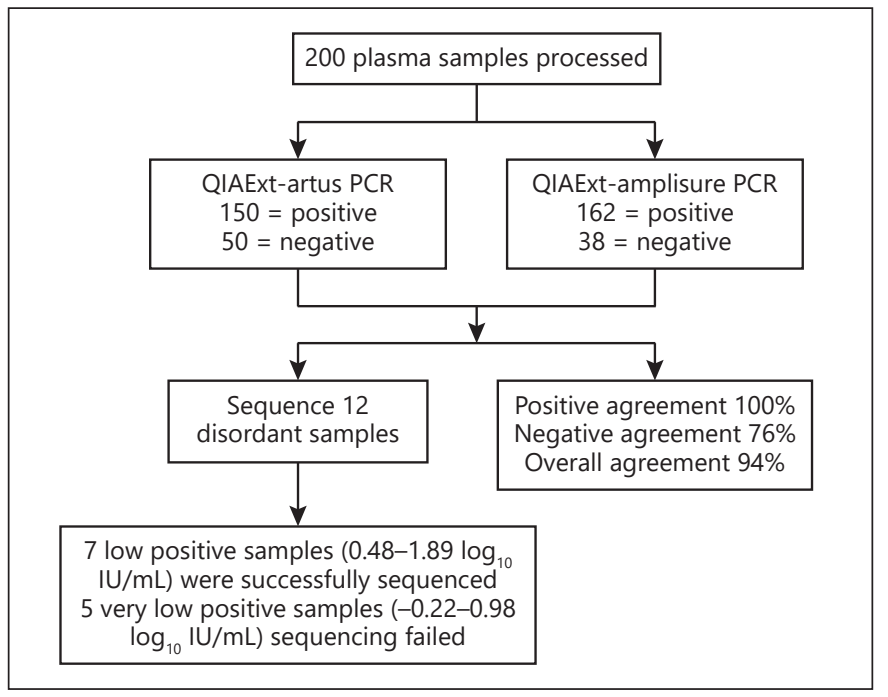

Fig. 2. Enlistment and outcome of the study.

\section{Statistical Analysis}

For this validation study, positive agreement and negative agreement for qualitative results values were calculated using Medcalc's diagnostic test evaluation calculator $[15,16]$. The differences between 2 methods were presented in a Bland-Altman plot, and linear regression analysis was used for $r^{2}$ determination [17].

\section{Results}

The results of performance characteristic of Amplisure ${ }^{\circledR}$ HBV Quantitative Kit as compared to the comparator method are shown in Figure 2. The overall perfor- 
Table 2. Amplisure $\mathrm{HBV}$ in comparison with the comparator method

\begin{tabular}{lrrrr}
\hline & & \multicolumn{3}{l}{ Artus HBV DNA } \\
\cline { 3 - 5 } & & + & - & total \\
\hline Amplisure HBV & + & 150 & 12 & 162 \\
& - & 0 & 38 & 38 \\
\hline Total & & 150 & 50 & 200 \\
\hline
\end{tabular}

Table 3. Agreement between the 2 methods

\begin{tabular}{lc}
\hline & $\begin{array}{l}\text { Amplisure versus artus as a } \\
\text { comparator test }\end{array}$ \\
\hline Positive agreement & $100(97.57-100.00)$ \\
Negative agreement & $76(61.83-86.94)$ \\
Overall agreement & $94(89.75-96.86)$ \\
\hline \multicolumn{1}{c}{ Data are presented as \%. Figures in the brackets indicate 95\% } \\
confidence interval.
\end{tabular}

Table 4. Comparison of artus QS-RGQ assay (IU/mL) and Amplisure HBV Quantitative Kit (IU/mL) assay by means of SD and \% CV as per log values

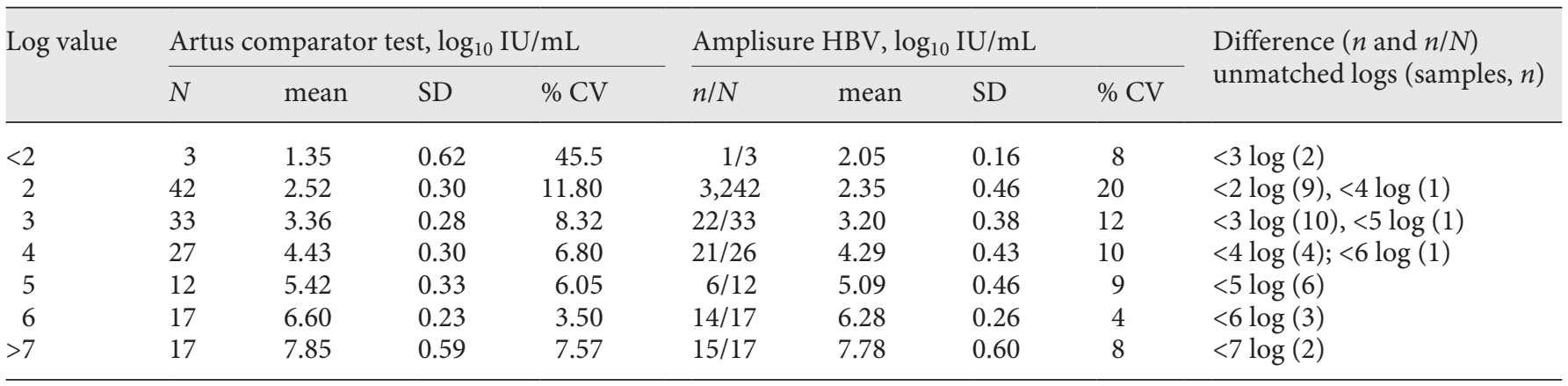

$N$, number of samples/log by artus assay QS-RGQ assay; $n / N$, number of samples/log by Amplisure ${ }^{\circledR}$ HBV Quantitative Kit. Data are presented as mean plus standard deviation; IU, international unit; $\mathrm{mL}$, milliliter.

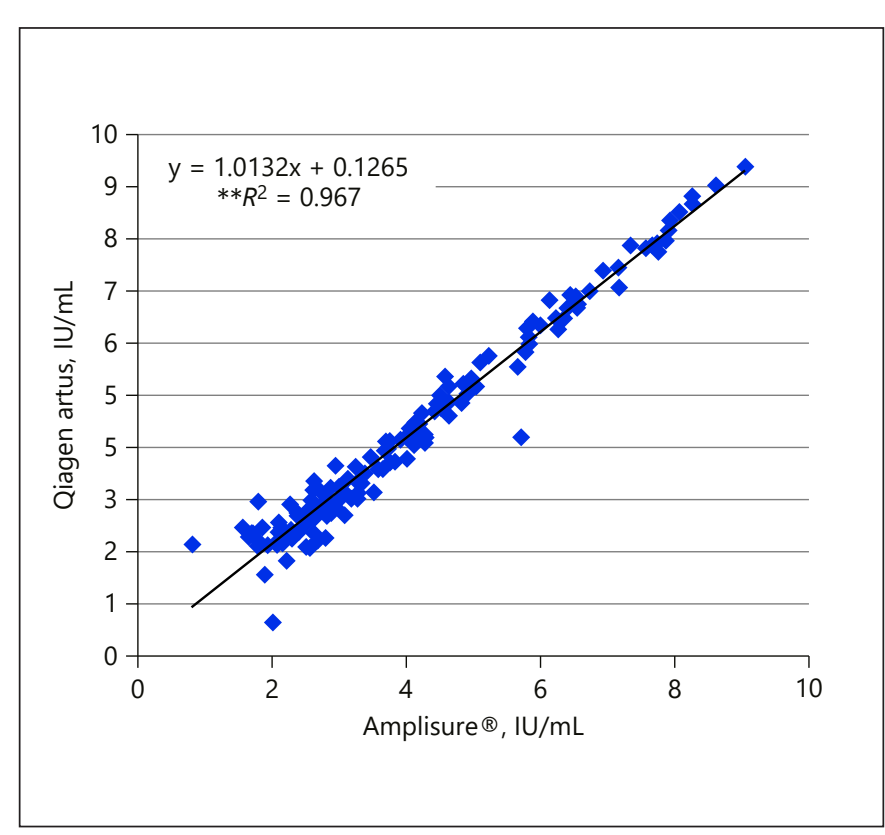

Fig. 3. Linear regression analysis shows the comparison of the comparator method and Amplisure HBV DNA. mance of the test method, Amplisure HBV, as compared with the comparator method shows that out of 200 samples, 188 samples were concordant and 12 samples showed discordant results (Table 2). These 12 (6\%) discordant results have low viral load ranging from -0.22 to $1.89 \log _{10}$ $\mathrm{IU} / \mathrm{mL}$ according to Amplisure HBV quantification. The positive and negative agreements were 100\% (CI: $97.57-$ 100\%) and 76\% (CI: 61.83-86.94\%), respectively (Table 3).

Among the 200 plasma samples tested, HBV DNA was quantified in 150 samples (75\%) by both the assays; of these 150 samples, 39 samples show log differences while comparing both results (Table 4). There were $12(6 \%)$ samples not detected by the artus QS-RGQ assay but quantified by Amplisure ${ }^{\circledR}$ HBV Quantitative Kit. Ten of the discordant samples present viral load below the artus QS-RGQ assay LOD and the remaining two are below the $2 \mathrm{x}$ artus QS-RGQ assay LOD.

The viral loads quantified by Amplisure ${ }^{\circledR}$ HBV Quantitative Kit were insignificantly lower than those quantified by the artus QS-RGQ assay (mean difference of 0.09 $\log \mathrm{IU} / \mathrm{mL})$. A total of $4(2.7 \%)$ samples showed significant difference of $\geq 1 \log _{10} \mathrm{IU} / \mathrm{mL}$. 
Fig. 4. Bland-Altman analysis was performed to compare the comparator method and Amplisure HBV DNA.

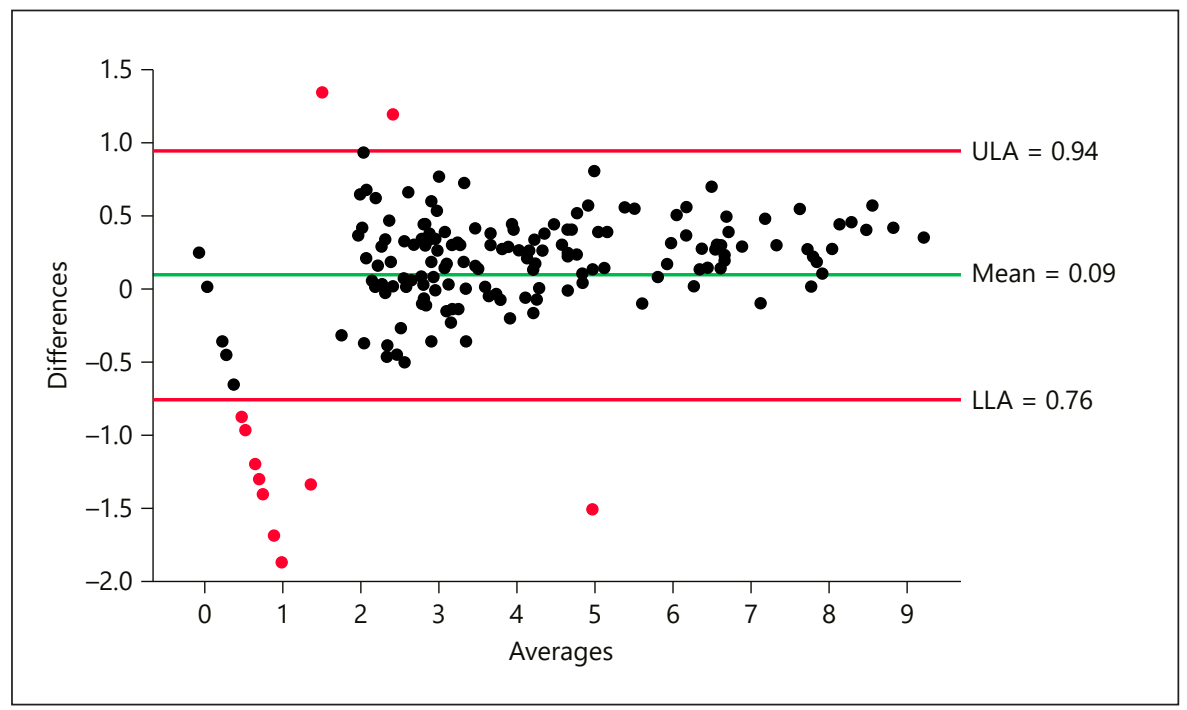

Table 5. Bland-Altman analysis result showing the mean log difference and LOA-ULA

\begin{tabular}{lr}
\hline Description & $\mathrm{IU} / \mathrm{mL}$ \\
\hline Mean $\log _{10} \mathrm{IU} / \mathrm{mL}$ difference & 0.09 \\
$\mathrm{LOA}, \log _{10} \mathrm{IU} / \mathrm{mL}$ & -0.76 \\
ULA, $\log _{10} \mathrm{IU} / \mathrm{mL}$ & 0.94 \\
\hline
\end{tabular}

IU, international unit; $\mathrm{mL}$, milliliter; LOA, lower limit of agreement; ULA, upper limit of agreement.

\section{Nested PCR and Sequencing Analysis}

The 12 discrepant qualitative results, all positive with Amplisure ${ }^{\circledR}$ HBV Quantitative Kit and negative with artus QS-RGQ assay, were taken for nested PCR and then sequenced. As most of the samples are of low viral load, we have selected the nested PCR approach. In spite of the nested PCR approach, concentration of the amplified products of 5 samples was less than the requirement for sequencing. All these 5 samples were below the detection limit of the comparator method, that is, below $40 \mathrm{IU} / \mathrm{mL}$. But, all those 5 samples were positive at the nested PCR level which was confirmed by agarose gel. Of these 12 discrepant samples, 7 were sequenced as genotype A (1), C (1), D (4), and E (1). For the remaining 5 samples, sequencing failed.

\section{Agreement and Correlation between the Assays}

As shown in Figure 3, linear regression analysis was done comparing Amplisure HBV and the comparator method. The correlation of $r^{2}=0.967$ shows good correlation of the techniques. The plot was performed to measure the agree- ment between the assays (Fig. 4). The difference between the HBV viral $\operatorname{load} \log _{10} \mathrm{IU} / \mathrm{mL}$ values of the 2 methods was plotted against the average of the $\log _{10} \mathrm{IU} / \mathrm{mL}$ results of the 2 methods. As shown in Table 5, the mean difference between Amplisure HBV and the comparator method is 0.09 $\log _{10} \mathrm{IU} / \mathrm{mL}$. The lower limit of agreement (LOA) is -0.76 , and the upper limit of agreement (ULA) is 0.94 .

\section{Discussion}

One of the important outcomes of HBV DNA testing has been the identification of patients who are HBsAg, anti-HBe positive but positive for HBV DNA. Such a clinical situation is associated with variations in ongoing chronic disease, fulminant acute hepatitis, acute nonfulminant hepatitis, and poor response to interferon therapy [18]; as this study was focused on active infection and the study was done on the leftover samples, we have not considered serological status of samples selected for comparison or for analysis.

HBV DNA quantification is essential for monitoring disease status and treatment response along with drug resistance detection in CHB patients. Until now, numerous commercially available RT-PCR assays have been developed for this. CHB is a foremost cause of hepatocellular carcinoma and cirrhosis in Southeast Asia, China, and Africa [19]. Newly launched Amplisure ${ }^{\circledR}$ HBV Quantitative Kit assay suggested an equivalent LOD and equivalent LOA to artus QS-RGQ assay by the manufacturer. This new assay has not been researched enough about its performance, so it is unable to compare findings with previous studies. 
In our study, there were differences between the artus QS-RGQ assay and the Amplisure ${ }^{\circledR}$ HBV Quantitative Kit assay in the detection rate and viral load when quantifying HBV DNA levels in clinical plasma samples. Correlation between the Qiagen artus assay with Amplisure ${ }^{\circledR}$ HBV Quantitative Kit assay, that is, Amplisure HBV, showed good positive agreement of 100\% (CI: 97.57-100) with an overall agreement of 94\% (89.75-96.86), and good correlation was observed $\left(r^{2}=0.967\right)$; it shows a comparable result with Qiagen artus assay.

However, there were only few samples which had significant log differences in the viral load quantification rate of Qiagen artus assay and Amplisure HBV Quantitative Kit assay. The HBV DNA levels determined by the Amplisure HBV were slightly lower than the results of the comparator method $\left(0.09 \log _{10} \mathrm{IU} / \mathrm{mL}\right.$ in mean). Overall, 4 samples showed $> \pm 1 \log$ difference ranging from 0.65 to $4.19 \log _{10} \mathrm{IU} / \mathrm{mL}$, and 23 samples showed $> \pm 0.5 \log _{10}$ $\mathrm{IU} / \mathrm{mL}$ difference viral loads ranging from 2.08 to 8.82 $\log _{10} \mathrm{IU} / \mathrm{mL}$. Bland-Altman shows a mean $\log _{10} \mathrm{IU} / \mathrm{mL}$ difference of $0.09 \log _{10} \mathrm{IU} / \mathrm{mL}$ and the LOA of -0.76 with a ULA of 0.94 .

The correlation between the results of the 2 assays in low viral load samples ( $<\log 2$ and 3 ) was not as strong as the correlation for all samples $(r=0.967)$. It is a known characteristic of PCR amplification that weak samples may present higher variability than strong ones. According to the manufacturer's protocol, the LOD of the Amplisure ${ }^{\circledR} \mathrm{HBV}$ Quantitative Kit assay is $18 \mathrm{IU} / \mathrm{mL}$ which is lower than that of the QS-RGQ assay at a laboratory, generated $40 \mathrm{IU} / \mathrm{mL}$. Consequently, QS-RGQ assay results showed a lower positive rate than the Amplisure ${ }^{\circledR}$ HBV Quantitative Kit in the samples for 1 and 2 log. There were 12 samples which showed qualitative discrepancy. All of the 12 samples were negative from the comparator method. Amplisure HBV results indicated that 7 samples have low viral load log ranging from 0.65 to 1.86 $\log _{10} \mathrm{IU} / \mathrm{mL}$, and all those were confirmed positive by sequencing. For the other 5 samples, sequencing failed probably due to even lower viral load (ranging from -0.22 to $0.98 \log _{10} \mathrm{IU} / \mathrm{mL}$ ). Ten of these 12 qualitative discrepant samples are below the Qiagen artus LOD and the two other are below twice the LOD of Qiagen artus.

Furthermore, 3 of the highest quantitative discrepancies between the assays were observed on low viral load (0.65-2.96 log IU/mL). Only 1 sample presents $>1 \log$ IU/ $\mathrm{mL}$ difference and a high viral load $4.19 \log \mathrm{IU} / \mathrm{mL}$ for artus QS-RGQ assay versus 6.59 $\log \mathrm{IU} / \mathrm{mL}$ for Amplisure ${ }^{\circledR}$ HBV Quantitative Kit. This sample was sequenced and gave a genotype $\mathrm{D}$ result. The good quantitative correla-

Comparison of HBV Viral Load between

Amplisure and Qiagen Artus Methods tion in medium/high load would lead to a similar classification of inactive $\mathrm{HBsAg}$ carriers and active $\mathrm{CHB}$ patients and may even change the $\mathrm{CHB}$ management strategy.

One more possibility for the sample discrepancies may be mutations in the core region of the 134-bp genome which may have led to the negative results of the comparator method, as all the samples were positive in the nested PCR which had type-specific primers as targets with BA1R (type A 68 bp), BB1R (type B 281 bp), BC1R (type C 122 bp), BD1 (type D 119 bp), BE1 (type E 167 $\mathrm{bp}$ ), and BF1 (type F $97 \mathrm{bp}$ ), while mutations in the core region would have not affected the Amplisure kit result as it targets the $S$ gene, so difference in the target regions of both the kits may have resulted in the sample discrepancies.

As studied before, there are several possible factors that may lead to assay discrepancies [10, 20, 21]. It has been reported that the HBV genotype $\mathrm{B}$ and low HBV viral load were 2 factors that contribute to significant differences in HBV DNA viral load detection, that is, $\geq 1 / 2$ $\log _{10} \mathrm{IU} / \mathrm{mL}$, when compared to the real-time HBV assay (Abbott Laboratories, Abbott Park, IL, USA) with CAP/ CTM v2.0 assay [9]. Also, identical results were observed previously in comparison with the Abbott real-time HBV assay and artus QS-RGQ assays on 2 different platforms. The difference was marginal, especially in samples with low viral load $(<2-3 \log )$ [22]. These observations are also applicable to our study for low viral load samples.

Another aspect for these discrepancies may be mutations in precore and core promoter regions. Mutations generally occur as $\mathrm{CHB}$ progresses and may affect the DNA quantification [23-25]. Also, few of the studies shed light on the detection difference between other assays in low viral load samples that may be influenced by the tyrosinemethionine-aspartate-aspartate mutation, which confers lamivudine resistance $[26,27]$. Thus, detection sensitivity for HBV mutants in the common target region may differ depending on the assay. We have performed genotyping to identify HBV genotypes. The data represented genotype D followed by genotype A and genotype $\mathrm{E}$.

In conclusion, the Amplisure ${ }^{\circledR}$ HBV Quantitative Kit assay shows good correlation with the Qiagen artus QSRGQ assay. This assay showed a slightly increased detection rate and similar viral load compared with results of the comparator method in plasma samples. Consequent to these results, it can be concluded that Amplisure ${ }^{\circledR}$ HBV Quantitative Kit assay showed comparable performance with Qiagen artus HBV QS-RGQ assay and can be useful in management and therapeutic monitoring of $\mathrm{HBV}$ infection. 


\section{Acknowledgement}

The reagents and consumables were provided by RAS Lifesciences, Hyderabad. RAS did not impact on study conduction and approval of the manuscript.

\section{Statement of Ethics}

The study is exempt from ethics committee approval. We obtained the waiver of consent as the study was carried out on leftover samples identified by a laboratory-generated number with no traceability to the patients. All patients' details were thus kept confidential. The Amplisure ${ }^{\circledR} \mathrm{HBV}$ Quantitative Kit results were not used in clinical decision-making.

\section{Conflict of Interest Statement}

The authors have no conflicts of interest to declare.

\section{Funding Sources}

This research did not receive any specific grant from funding agencies in the public, commercial, or not-for-profit sectors.

\section{Author Contributions}

P.K.G.: performing testing and writing the manuscript; C.N.: study design and verification of data and manuscript; C.S.: verification of data and manuscript; A.V.M.: reviewing the manuscript; Venkat and R.A.: study performers.

\section{References}

1 World Health Organization. Hepatitis B. Available from: http://www.who.int/mediacentre/factsheets/fs204/en/ Updated on 2016 Jul.

2 World health organization India Hepatitis B. Available from: http://www.searo.who.int/ india/topics/hepatitis/factsheet_b__hepatitis.

3 VPD Surveillance Manual 4 Hepatitis B: Chapter4.1. Available from: https://www.cdc. gov/vaccines/pubs/surv-manual/chpt04hepb.pdf.

4 Kuriakose M, Ittyachen AM. An investigation into the high prevalence of hepatitis B in a rural area of Kerala State, India: hypothesis on chrysops sp. (Diptera: Tabanidae) transmission. Biomed Res Int. 2018. Article ID 4612472.

5 Mendy ME, Kaye S, van der Sande M, RaycoSolon P, Waight PA, Shipton D, et al. Application of real-time PCR to quantify hepatitis B virus DNA in chronic carriers in The Gambia. Virol J. 2006;3:23.

6 Liu C, Chang L, Jia T, Guo F, Zhang L, Junpeng Zhao HJ, et al. Real-time PCR assays for hepatitis B virus DNA quantification may require two different targets. Virol J. 2017;14 94.

7 Stelzl E, Muller Z, Marth E, Kessler HH. Rapid quantification of hepatitis B virus DNA by automated sample preparation and real-time PCR. J Clin Microbiol. 2004;42:2445-9.

8 Poljak M, Lepej SZ, Rode OD. [Recent developments in serologic and molecular diagnosis of hepatitis B and C]. Acta Med Croatica. 2013;67:281-90.

9 Ismail AM, Sivakumar J, Anantharam R, Dayalan S, Samuel P, Fletcher GJ, et al. Performance characteristics and comparison of $\mathrm{Ab}$ bott and artus real-time systems for hepatitis $B$ virus DNA quantification. J Clin Microbiol. 2011;49:3215-21.
10 Ming-Lun Y, Chung-Feng H, Ming-Yen H, Jee-Fu H, Chia-Yen D, Ming-Lung Y, et al. Comparison of the Abbott RealTime HBV assay with the Roche Cobas AmpliPrep/Cobas TaqMan HBV assay for HBV DNA detection and quantification. J Clin Virol. 2014;60:20614.

11 Naito H, Hayashi S, Abe K. Rapid and specific genotyping system for hepatitis B virus corresponding to six major genotypes by PCR using type-specific primers. J Clin Microbiol. 2001 Jan;39:362-4. 0095-1137/01/\$04.0010.

12 Amplisure HBV Quantitative Assay (Real Time PCR Assay insert).

13 Naito H, Hayashi S, Abe K. Rapid and specific genotyping system for hepatitis B virus corresponding to six major genotypes by PCR using type-specific primers [published correction appears in J Clin Microbiol $2001 \mathrm{Apr}$; 39(4):1686]. J Clin Microbiol. 2001;39(1): $362-4$.

14 ExoSAP-IT PCR Product cleanup Catalog Number 78200, 78201, 78202, 78205, and 78250 Doc. Part No. 78200 b Pub. No. MAN0016836 Rev. A.0 (02/2017).

15 Bossuyt PM, Reitsma JB, Bruns DE. Towards complete and accurate reporting of studies of diagnostic accuracy: the STARD initiative. Clin Biochem. 2003;36(1):2-7.

16 Avialable from: https://www.medcalc.org/ calc/diagnostic_test.php.

17 Landis JR, Koch GG. The measurement of observer agreement for categorical data. Biometrics. 1977;33:159-74.

18 Lahiri KK, Sahni AK, Gupta RM, Duhan SD, Kapila K, Jena J. Hepatitis B e Antigen negative chronic hepatitis in indian patients : a reality. Med J Armed Forces India. 2007 Oct; 63(4):318-21.

19 Lok AS. Natural history and control of perinatally acquired hepatitis B virus infection. Dig Dis. 1992;10:46-52.
20 Fielder H, Javed S, Marques C, Wall G, Lange C, Tomlinson D. Quantitative detection of hepatitis B virus (HBV) DNA with the novel artus $^{\oplus}$ HBV QS-RGQ Kit version 2. J Clin Virol. 2015;70:S85.

21 Chevaliez S, Bouvier-Alias M, Laperche S, Hézode C, Pawlotsky JM. Performance of version 2.0 of the Cobas AmpliPrep/Cobas TaqMan real-time PCR assay for hepatitis B virus DNA quantification. J Clin Microbiol. 2010; 48:3641-7.

22 Caliendo AM, Valsamakis A, Bremer JW, Ferreira-Gonzalez A, Granger S, Sabatini L. Multilaboratory evaluation of real-time PCR tests for hepatitis B virus DNA quantification. J Clin Microbiol. 2011;49:2854-8.

23 Funk ML, Rosenberg DM, Lok AS. Worldwide epidemiology of HBeAg-negative chronic hepatitis B and associated precore and core promoter variants. J Viral Hepat. 2002;9:52-61.

24 Lindh M, Hannoun C, Malmström S, Lindberg J, Norkrans G. Lamivudine resistance of hepatitis $B$ virus masked by coemergence of mutations in probe region of the COBAS AMPLICOR assay. J Clin Microbiol. 2006;44: 2587-9.

25 Yeh ML, Huang CF, Huang CI, Liu SF, Yang HL, Hsieh MY, et al. Abbott RealTime HBV assay is more sensitive in detection of low viral load and little impacted by drug resistant mutation in chronic hepatitis B patients under nucleot(s)ide analogues therapy. PLoS One. 2014;9:e101790.

26 Alestig E, Hannoun C, Horal P, Lindh M. Phylogenetic origin of hepatitis $B$ virus strains with precore C-1858 variant. J Clin Microbiol. 2001;39:3200-3.

27 Alexopoulou A, Karayiannis P. HBeAg negative variants and their role in the natural history of chronic hepatitis B virus infection. World J Gastroenterol. 2014;20:7644-52. 